\title{
Synthesis and Biological Evaluation of S-Substituted Perhalo-2-nitrobuta-1,3-dienes as Novel Xanthine Oxidase, Tyrosinase, Elastase, and Neuraminidase Inhibitors
}

\author{
Nihal Onul $\mathbb{D}^{1},{ }^{1}$ Onur Ertik $\mathbb{D},{ }^{2}$ Neşe Mermer $\mathbb{D}^{1},{ }^{1}$ and Refiye Yanardag $\mathbb{D}^{2}$ \\ ${ }^{1}$ Organic Chemistry Division, Department of Chemistry, Faculty of Engineering, Istanbul University, Avcilar, 34320 Istanbul, Turkey \\ ${ }^{2}$ Biochemistry Division, Department of Chemistry, Faculty of Engineering, Istanbul University, Avcilar, 34320 Istanbul, Turkey \\ Correspondence should be addressed to Nihal Onul; yilm@istanbul.edu.tr
}

Received 7 August 2017; Revised 13 November 2017; Accepted 27 November 2017; Published 31 January 2018

Academic Editor: Xinyong Liu

Copyright ( $\odot 2018$ Nihal Onul et al. This is an open access article distributed under the Creative Commons Attribution License, which permits unrestricted use, distribution, and reproduction in any medium, provided the original work is properly cited.

S-substituted perhalo-2-nitrobuta-1,3-dienes $\mathbf{3 a}, \mathbf{b}$ were synthesized by the reaction of polyhalo-2-nitrobuta-1,3-dienes $\mathbf{1 a}, \mathbf{b}$ with allyl mercaptan. 1-(2,3-Dibromopropanethio)-4-bromo-1,3,4-trichloro-2-nitrobuta-1,3-diene 4 was obtained from the addition of bromine to S-substituted polyhalo-2-nitrobuta-1,3-diene $\mathbf{3 b}$ in carbon tetrachloride. Sulfoxides $\mathbf{5 a}$, $\mathbf{b}$, and $\mathbf{6}$ were obtained from the reaction of thiosubstituted polyhalonitrobutadienes $\mathbf{3 a}, \mathbf{b}$, and 4 with $m$-CPBA in $\mathrm{CHCl}_{3}$. The structures of the new compounds were determined by spectroscopic data (FTIR, ${ }^{1} \mathrm{H}$ NMR, ${ }^{13} \mathrm{C}$ NMR, MS). These compounds exhibited antixanthine oxidase, antityrosinase, antielastase, and antineuraminidase activities.

\section{Introduction}

Nitro-substituted polyhalobuta-1,3-dienes, regarding their intriguing chemical and biological properties, have been in the organic compound families that were preferred by researchers. Nitro-containing polyhalobuta-1,3-dienes especially play a role in building blocks in organic syntheses. Due to the presence of the nitro group it contains, the compound 2-nitropolyhalobuta-1,3-diene easily gives the vinylic substitution $\left(S_{N} V i n\right)$ reactions. These nitro derivatives are used as building pioneering blocks for polyfunctional acyclic and heterocyclic compounds' syntheses with biological activity. These synthesized compounds are important in pharmacology. S-, N-, N,S-substituted polyhalonitrobutadiene compounds obtained by the reactions of polyhalonitrobutadiene compounds with various nucleophilic reagents such as thiols, dithiols, and amines are given in the literature [1-9]. There are studies on antifungal, antibacterial, anticancer, and anti-HIV properties of these compounds [10-16]. Moreover, there are patents about the properties of these substances [17-19].

Allylthiol derivatives, selected as the nucleophile, have diverse biological activities. These derivatives show antibacterial, anti-inflammatory, antithrombotic, anticancer, and antiatherosclerotic properties. Most of these effects are due to the $\mathrm{SH}$ group [20-24]. At the same time, allylthio compounds are seen to decrease cholesterol and triglyceride levels in humans and animals $[25,26]$.

Sulfoxide compounds, also synthesized in our work, have unique synthetic application to be used in synthetic studies. In the literature, these compounds have been termed as "chemical chameleons." They are used as synthetic mediators in the syntheses of several organic compounds having antiulcer, antibacterial, antifungal, and antihypertensive properties [27-29].

Xanthine oxidase (XO, EC: 1.1.3.22) is a complex metalloflavoprotein. This enzyme catalyzes the oxidation of hypoxanthine to xanthine and produces uric acid which leads to many diseases like gout and hyperuricemia [30]. High $\mathrm{XO}$ activity leads to accumulation of the uric acid in blood. Hyperuricemia and gout diseases are risks of cardiovascular disease [31] and chronic kidney disease. Excessive uric acid levels in blood cause insulin resistance. Also, hyperuricemia is related to type 2 diabetes, metabolic syndrome, hypertension, kidney disease, hepatitis, inflammation, ischemiareperfusion, carcinogenesis, and ageing. $\mathrm{XO}$ is responsible for 
oxidative damage that causes many pathological diseases, such as gout, hyperuricemia, atherosclerosis [32], hepatitis, carcinogenesis [33], metabolic syndrome [34], vascular endothelium damage, and ageing. For this reason, inhibition of $\mathrm{XO}$ has been an obvious target to control uric acid level in blood. It has been shown that XO inhibitors may be useful for the treatment of hepatic disease, cancer, inflammation, and gout which is caused by the generation of uric acid and superoxide anion radical [35].

Tyrosinase (EC: 1.14.18.1) is a copper containing bifunctional enzyme. This enzyme is widely distributed in plants, microorganisms, fungi, and animals [36]. Tyrosinase is also responsible for the production of neuromelanin. Excessive production of dopaquinone by oxidation of dopamine results in neuronal damage and cell death [37]. For this reason, this enzyme contributed to the neurodegeneration associated with Parkinson's disease and other neurodegenerative disease processes [38]. Also, cancers are characterized by abnormalities in tyrosinase activity [39]. Tyrosinase is also associated with the host defense, wound healing, melting, and sclerotization of insects [40]. Tyrosinase inhibitors were widely used in food, agriculture, and cosmetic industries and in the control of molting process of insects. Many natural and synthetic tyrosinase inhibitors have been reported such as ascorbic acid, arbutin, kojic acid, aromatic alcohols, azelaic acids, and aldehydes and polyphenol compounds such as resveratrol in recent years [41]. However, most of them suffered from limitations such as low activity, high toxicity, and insufficient penetrative ability. Also, these substances have lower therapeutic effect, mutagenicity, and cytotoxicity potential. For this reason, the development of novel, potent nontoxic and stable tyrosinase inhibitors has a great importance in the medical, cosmetic, and agricultural fields.

Elastase (EC: 3.4 .21 .37 ) is a serine protease of the chymotrypsin family that hydrolytically degrades extracellular matrix components such as elastin, fibronectin, collagen, proteoglycans, laminin, and some matrix metalloproteinases [42]. This enzyme is particularly abundant in the skin, arteries, lungs, and ligaments. Neutrophil elastase plays an important role in some processes like blood coagulation, apoptosis, and inflammation. Inhibition of the elastase activity could be used for protection against various diseases such as chronic obstructive pulmonary disease, cystic fibrosis, acute respiratory distress syndrome, acute lung injury, ischemia, and reperfusion injury [42]. Neutrophil elastase also plays a main role in both acute pathogenesis and chronic functional recovery after traumatic brain injury [43].

Neuraminidase (NA, EC: 3.2.1.18) is one of the two glycoproteins on the surface of influenza virus. NA activity is increased in the serum patients and animal models of sepsis. This event indicates that NA is associated with the pathogenesis of inflammation during infection [44]. NA is a key validated drug target in commercially available antiviral drugs. NA inhibitors, such as zanamivir, peramivir, and oseltamivir are commonly used for prevention and treatment of influenza [45]. NA inhibitors are in wide use for the treatment of influenza [46]. In the literature, thiourea and thiadiazole compounds have been reported to be effective against HIV and to have bacterial action [47].
Enzymes are biological macromolecules that accelerate or catalyze chemical reactions in biological systems. Some chemical, natural compounds and drugs alter normal enzyme activities by specific enzyme inhibition [48].

The increasing activities of enzyme cause different types of damage in the body. In this study, firstly we aimed to synthesize S-substituted perhalonitrobutadienes. The synthesized compounds were characterized by FTIR, ${ }^{1} \mathrm{H}$ NMR, ${ }^{13} \mathrm{C}$ NMR, MS. The second aim of this study is to investigate the xanthine oxidase, tyrosinase, elastase, and neuraminidase inhibition effect of these S-substituted perhalonitrobuta-1,3diene compounds. The inhibition of these enzymes is important for the treatment of many diseases such as gout, influen$\mathrm{za}$, and cancer.

\section{Results and Discussion}

2.1. Synthesis of S-Substituted Perhalonitrobuta-1,3-dienes. In our previous works, polyhalonitrobutadienes reacted with several thiols, and mono-, di-, and tri-(thio)substituted polyhalonitrobutadiene derivatives were synthesized [49-53]. In this work, 1,1,3,4,4-pentachloro-2-nitrobuta-1,3-diene (1a) [54] and 4-bromo-1,1,3,4-tetrachloro-2-nitro-1,3-butadiene (1b) [55] reacted with allyl mercaptan (2) in equimolar ratio at room temperature. Compounds $\mathbf{1 a}$ and $\mathbf{1} \mathbf{b}$ gave vinylic substitution reaction at room temperature and with the absence of solvent because of the reactivity of terminal carbon having nitrodichlorovinyl, and they yielded monosubstituted polyhalobutadiene compounds $\mathbf{3 a}$ [49] and $\mathbf{3 b}$ [50]. It has been reported that mono(thio)substitution nitrodienes are (E) isomers in previous studies [56-58]. As a consequence, it might be thought that derived new S-Substituted nitrodiene products were probably $(E)$ isomers. The thiosubstituted $\mathbf{3 b}$ compound gave the reaction of addition of bromine to the double bond in the allyl group in the presence of carbon tetrachloride. In the second phase of the study, the thiosubstituted compounds obtained were subjected to oxidation reactions.

Compounds $\mathbf{3 a}, \mathbf{3 b}$, and $\mathbf{4}$ were subjected to oxidation with $\mathrm{m}$-chloroperbenzoic acid in chloroform at $0^{\circ} \mathrm{C}$ to oxidize the thioether group. After the reactions, new sulfoxide derivatives $\mathbf{5 a}, \mathbf{5 b}$, and $\mathbf{6}$ were obtained (Scheme 1).

The compound $\mathbf{3 b}$ yielded ${ }^{13} \mathrm{C}-\mathrm{NMR}$ peaks as the following: methylene carbon bound to sulfur at $\delta=37.7 \mathrm{ppm}$, $\mathrm{CH}=$ group for allyl substituent at $\delta=129 \mathrm{ppm}$, and the $=\mathrm{CH}_{2}$ carbon at $\delta=120.4 \mathrm{ppm}$. The compound 4 , which is the bromine added product of $\mathbf{3 b}$, yielded the following ${ }^{13} \mathrm{C}$ NMR data: $\mathrm{CH}-\mathrm{Br}$ carbon in the propyl group at $\delta=46.1 \mathrm{ppm}$ and the $\mathrm{CH}_{2}-\mathrm{Br}$ carbon at $\delta=33.6 \mathrm{ppm}$. At the same time, ${ }^{1} \mathrm{H}$-NMR spectrum shows the propyl group protons instead of the characteristic $\mathrm{CH}=$ group for allyl system and $\mathrm{CH}_{2}=$ group. Methylene protons bound to sulfur, in compound 4, yielded ${ }^{1} \mathrm{H}-\mathrm{NMR}$ peaks in the range $\delta=3.3-3.5 \mathrm{ppm}$, $\mathrm{CH}_{2}$ protons bound to bromine atoms at $\delta=3.6-3.9$, and $\mathrm{CH}$ proton at $\delta=4.2-4.3 \mathrm{ppm}$. These data show that the double bond in the allyl group formed an added product with bromine. Meanwhile, in MS, the compound 4, which is an addition product, had a molecular ion peak at $531.3[\mathrm{M}+$ $\left.\mathrm{NH}_{4}\right]^{+}$. Oxidation reactions are successful when the sulfoxide compounds $\mathbf{5 a}, \mathbf{5 b}$, and $\mathbf{6}$ are viewed in terms of spectroscopic 

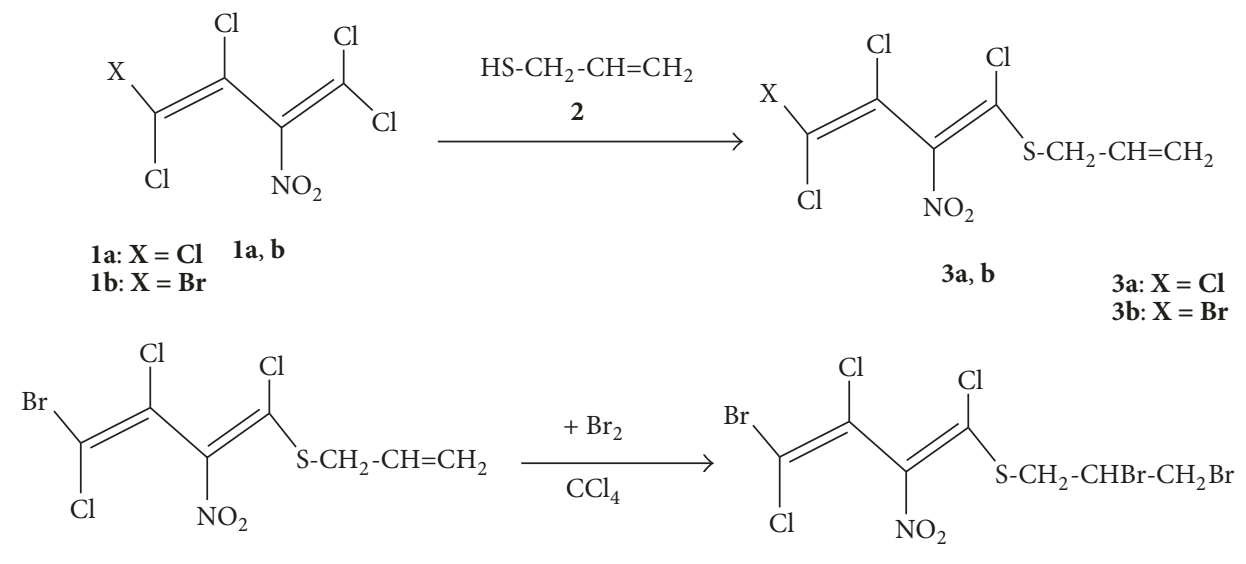

$3 b$

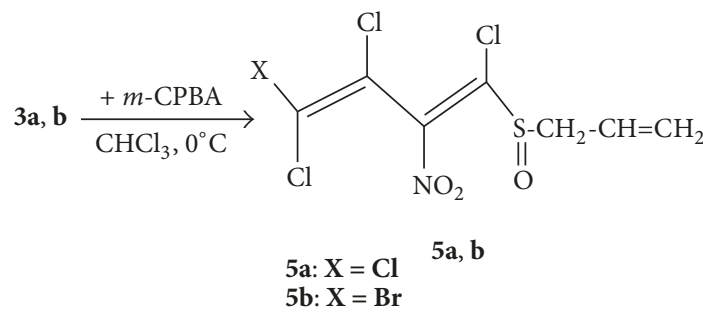<smiles>C[C@H](Br)[C@@H](Br)C[S@@](=O)C(Cl)=C(C(Cl)=C(Cl)Br)[N+](=O)[O-]</smiles>

6

Scheme 1: Synthesis of S-substituted perhalonitrobuta-1,3-diene compounds.

data. FTIR data of $\mathbf{5} \mathbf{a}$ and $\mathbf{5} \mathbf{b}$ showed characteristic $\mathrm{S}=\mathrm{O}$ band at $1071 \mathrm{~cm}^{-1}$, and FTIR data of $\mathbf{6}$ showed characteristic $\mathrm{S}=\mathrm{O}$ band observed at $1073 \mathrm{~cm}^{-1}$. Compound 5 a yielded molecular ion peak at $326[\mathrm{M}+\mathrm{H}]^{+}$in the mass spectrum, whereas compound $\mathbf{5 b}$ yielded molecular ion peak at $369.9[\mathrm{M}+\mathrm{H}]^{+}$. When the mass spectrum of compound $\mathbf{6}$ is investigated, the ion peak is at $548.15\left[\mathrm{M}+\mathrm{NH}_{4}\right]^{+}$and a disintegration product which is the result of a loss of chlorine atom is at $492.5[\mathrm{M}+$ $\left.\mathrm{NH}_{4}-\mathrm{Cl}\right]^{+}$.

2.2. Enzyme Inhibition. The xanthine oxidase inhibitory activities of S-substituted perhalonitrobuta-1,3-diene compounds were given in Table 1 . All the test compounds exhibited antixanthine oxidase activities (Table 1). The xanthine oxidase inhibitory activities of S-substituted perhalonitrobuta-1,3-diene compounds were found to increase in dose depending manner. Low $\mathrm{IC}_{50}$ values indicate the higher enzyme inhibitory activity. Antixanthine oxidase activity of S-substituted perhalonitrobuta-1,3-diene compounds and standard decreased in the order of allopurinol $>4>5 b>$ $6>5$ a. All these compounds showed variable inhibition values ranging from 86.72 to $4094.61 \mu \mathrm{M}$ for XO while compound 4 showed the lowest $\mathrm{IC}_{50}$ values $(86.72 \pm 3.20 \mu \mathrm{M})$. We also compared our inhibition values to allopurinol that is frequently used as $\mathrm{XO}$ inhibitor in gout disease. $\mathrm{IC}_{50}$ value of allopurinol was $3.61 \pm 0.31 \mu \mathrm{M}$ lesser than our inhibition results of S-substituted perhalonitrobuta-1,3dienes. However, allopurinol shows some adverse effects such as rash hepatitis, nephropathy, allergic reactions, vasculitis eosinophilia, and renal failure [59]. For this reason, new inhibitor, which has nonadverse effects, is needed. 4 was the most potent inhibitor against $\mathrm{XO}$ among the tested compounds. Compound 5a has low XO inhibitory activity. Compounds $\mathbf{5 b}$ and $\mathbf{6}$ show similar XO inhibitory activities. Their $\mathrm{IC}_{50}$ values are $3145.08 \pm 79.08$ and $3480.15 \pm 32.84 \mu \mathrm{M}$. In the compound 4 , there is a free sulfur group and this sulfur group has two unpaired electrons. Molybdenum is in the active center of XO. Molybdenum and sulfur atoms can be found in a complex and this complex formation shows inhibitory effects on XO. It has been pointed out in the literature that compounds with sulfur atoms in the structure exhibit xanthine oxidase inhibitor activity [60].

It has been reported by Song et al. (2015) that febuxostat with sulfur in its structure inhibits the enzyme XO at a high rate. It was determined that the enzyme inhibited is similar to allopurinol in compound 4 which had a free sulfur group in its structure [61].

All compounds clearly showed a concentration dependent inhibition against tyrosinase activity (Table 2). Low $\mathrm{IC}_{50}$ values indicate higher enzyme inhibitor activity. The results show that compounds $\mathbf{5 b}$ and $\mathbf{6}$ could inhibit tyrosinase. As shown in Table 2 the $\mathrm{IC}_{50}$ values of $\mathbf{5 b}$ and $\mathbf{6}$ were similar. 
TABLE 1: The xanthine oxidase inhibitory activity of different concentrations of S-substituted perhalonitrobuta-1,3-diene compounds.

\begin{tabular}{|c|c|c|c|}
\hline $\begin{array}{l}\text { Chemical compounds and } \\
\text { standard }\end{array}$ & Concentration $(\mu \mathrm{M})$ & Inhibition $(\%)^{*}$ & $\mathrm{IC}_{50}(\mu \mathrm{M})^{*}$ \\
\hline \multirow{5}{*}{4} & 100 & $55.07 \pm 1.93$ & \multirow{5}{*}{$86.72 \pm 3.20$} \\
\hline & 50 & $33.82 \pm 0.97$ & \\
\hline & 25 & $21.26 \pm 0.97$ & \\
\hline & 10 & $15.77 \pm 1.46$ & \\
\hline & 1 & $3.38 \pm 0.84$ & \\
\hline \multirow{5}{*}{$5 a$} & 500 & $8.14 \pm 0.48$ & \multirow{5}{*}{$4094.61 \pm 213.20$} \\
\hline & 250 & $6.46 \pm 0.24$ & \\
\hline & 100 & $4.90 \pm 0.17$ & \\
\hline & 50 & $3.55 \pm 0.18$ & \\
\hline & 25 & $1.92 \pm 0.83$ & \\
\hline \multirow{5}{*}{$5 b$} & 1000 & $16.59 \pm 1.81$ & \multirow{5}{*}{$3145.08 \pm 79.08$} \\
\hline & 750 & $12.69 \pm 0.25$ & \\
\hline & 500 & $7.66 \pm 0.48$ & \\
\hline & 250 & $4.90 \pm 1.26$ & \\
\hline & 100 & $2.55 \pm 1.21$ & \\
\hline \multirow{5}{*}{6} & 500 & $10.77 \pm 0.72$ & \multirow{5}{*}{$3480.15 \pm 32.84$} \\
\hline & 250 & $7.50 \pm 0.55$ & \\
\hline & 100 & $6.19 \pm 0.55$ & \\
\hline & 50 & $3.47 \pm 0.50$ & \\
\hline & 25 & $2.80 \pm 0.14$ & \\
\hline \multirow{5}{*}{ Allopurinol } & 10 & $96.29 \pm 1.61$ & \multirow{5}{*}{$3.61 \pm 0.31$} \\
\hline & 5 & $77.78 \pm 2.45$ & \\
\hline & 1 & $28.40 \pm 1.93$ & \\
\hline & 0.5 & $24.36 \pm 0.54$ & \\
\hline & 0.1 & $5.25 \pm 1.42$ & \\
\hline
\end{tabular}

${ }^{*}$ Mean \pm SD.

TABLE 2: The tyrosinase inhibitory activity of different concentrations of S-substituted perhalonitrobuta-1,3-diene compounds.

\begin{tabular}{|c|c|c|c|}
\hline $\begin{array}{l}\text { Chemical compounds and } \\
\text { standard }\end{array}$ & Concentration $(\mu \mathrm{M})$ & Inhibition $(\%)^{*}$ & $\mathrm{IC}_{50}(\mu \mathrm{M})^{*}$ \\
\hline \multirow{5}{*}{ 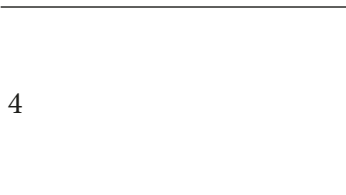 } & 2000 & $40.98 \pm 3.04$ & \multirow{5}{*}{$2497.42 \pm 196.40$} \\
\hline & 1000 & $22.62 \pm 1.04$ & \\
\hline & 500 & $13.82 \pm 0.57$ & \\
\hline & 250 & $10.24 \pm 2.12$ & \\
\hline & 125 & $5.37 \pm 1.29$ & \\
\hline \multirow{5}{*}{$5 a$} & 2000 & $30.53 \pm 0.93$ & \multirow{5}{*}{$3465.46 \pm 174.24$} \\
\hline & 1000 & $22.90 \pm 1.09$ & \\
\hline & 500 & $17.34 \pm 1.00$ & \\
\hline & 250 & $11.94 \pm 1.44$ & \\
\hline & 125 & $5.09 \pm 1.40$ & \\
\hline \multirow{5}{*}{$5 b$} & 2000 & $90.89 \pm 0.94$ & \multirow{5}{*}{$538.19 \pm 82.47$} \\
\hline & 1000 & $68.54 \pm 1.54$ & \\
\hline & 500 & $57.05 \pm 2.63$ & \\
\hline & 250 & $43.20 \pm 2.50$ & \\
\hline & 125 & $26.28 \pm 4.30$ & \\
\hline \multirow{5}{*}{6} & 2000 & $99.37 \pm 0.44$ & \multirow{5}{*}{$513.26 \pm 6.97$} \\
\hline & 1000 & $86.61 \pm 0.22$ & \\
\hline & 500 & $58.59 \pm 1.44$ & \\
\hline & 250 & $38.01 \pm 2.79$ & \\
\hline & 125 & $20.46 \pm 4.22$ & \\
\hline \multirow{5}{*}{ Kojic acid } & 1000 & $98.24 \pm 0.22$ & \multirow{5}{*}{$291.01 \pm 8.13$} \\
\hline & 500 & $85.35 \pm 1.33$ & \\
\hline & 250 & $58.71 \pm 2.96$ & \\
\hline & 125 & $32.95 \pm 2.63$ & \\
\hline & 60 & $14.52 \pm 1.53$ & \\
\hline
\end{tabular}

${ }^{*}$ Mean \pm SD. 
However, $\mathrm{IC}_{50}$ values of $\mathbf{4}$ and $\mathbf{5 a}$ compounds were higher. Antityrosinase activity of S-substituted perhalonitrobuta-1,3diene compounds and standard decreased in the order of kojic acid $>6>5 b>4>5 a$. Sulfur containing compounds, such as thiourea, thiosemicarbazone, and thiocarbonyl compounds can form chelate with transition metal ions. In the literature, thiosemicarbazone derivatives had been reported to be efficient tyrosinase inhibitors [62]. The inhibitory effect of thiosemicarbazone derivatives on tyrosinase exhibited potent inhibitory activity. The reason of this may be that the sulfur atom in the structure of the compound can chelate the two copper ions in the active side of enzyme. Many thiourea derivatives were known to be competitive inhibitors of tyrosinase due to their chelating ability to copper ions at the active sites [63]. It was reported in the literature that sulfur atoms inhibit tyrosinase via bonding the copper ions in the active site of the enzyme [64]. Liu et al. found that thiosemicarbazone derivatives showed high tyrosinase inhibition [65]. According to a previous study thio groups containing compounds act as o-dopaquinone scavengers [66]. In our study, it can be claimed that sulfur atom which is found in compound 6 inhibited the enzyme by binding to the copper ion at the active site.

Inhibition effects of elastase activities are shown in Table 3. The elastase inhibitor activities of S-substituted perhalonitrobuta-1,3-diene compounds were found to increase in a dose depending manner (Table 3). The inhibition was increased with increasing S-substituted perhalonitrobuta-1,3dienes concentration. Amongst the compounds, the best inhibition was found for the compound $\mathbf{4}$, followed by the $\mathbf{6}$, $\mathbf{5 b}$, and $5 \mathbf{a}$. A high elastase inhibition $(58.55 \pm 2.37 \%)$ was seen at $2000 \mu \mathrm{M}$ for 4 and its $\mathrm{IC}_{50}$ value was $1476.79 \pm 56.03 \mu \mathrm{M}$. However, $\mathbf{5 b}$ and $\mathbf{6}$ showed nearly the same inhibition. The inhibitory potency of compounds was in the order of ursolic acid $>\mathbf{4}>\mathbf{6}>\mathbf{5 b}>\mathbf{5 a}$. In our study, it was seen that S-substituted perhalonitrobuta-1,3-diene compounds inhibit elastase in low ratio. It was reported by Stolk et al. [67] that thiol agent has an effect on elastase activity. In addition, Rodis and Digenis [68] reported that low molecular weight thiocarbamate compounds also have inhibitory effect on leukocyte elastase activity. Sokmen et al. showed that triazole compounds which include halogen, carboxylate, heterocyclic sulfide, sulfone, and/or methoxy groups in their structure inhibit elastase enzyme [42]. In our study, it can be assumed that compounds which have halogen and sulfoxide groups in their structure inhibit elastase enzyme, yet, not in high ratio.

The neuraminidase inhibition activities of S-substituted perhalonitrobuta-1,3-diene compounds were given in Table 4. NA inhibitory activities of S-substituted perhalonitrobuta1,3-diene compounds were found to increase in a dose dependent manner. Amongst them, the best inhibition was found for the compound $\mathbf{6}$. All compounds clearly showed a concentration dependent inhibition against neuraminidase activity. The inhibitory effect of compound $\mathbf{6}$ on neuraminidase activity was better than quercetin. Antineuraminidase activity of $4,5 a, 5 b$, and 6 decreased in the order of $6>$ quercetin $>$ $\mathbf{5 b}>\mathbf{5 a}>\mathbf{4}$. It was found that the compounds which have sulfoxide groups have higher NA inhibitory activity. A higher $\mathrm{NA}$ inhibitor activity is associated with a lower $\mathrm{IC}_{50}$ value.
Compound 6 that contained halogen atoms and sulfoxide group showed excellent inhibitory activities. The inhibitory potential of compounds $\mathbf{5 b}$ and $\mathbf{5 a}$ was found greater than that of 4 . Compound $\mathbf{6}$ demonstrated higher neuraminidase inhibition activity than that of quercetin (Table 4). A Ki value is the binding affinity constant of each inhibitor. Compound 6 was the best neuraminidase inhibitor $(\mathrm{Ki}=108.37 \pm$ $14.65 \mu \mathrm{M})$. Quercetin showed a Ki value of $124.83 \pm 14.95 \mu \mathrm{M}$ against neuraminidase activity. The inhibition mechanisms of compound $\mathbf{6}$ and quercetin were competitive. The quercetin which is a natural flavonoid has antiviral property [69-71]. This substance was used as standard substance for antineuraminidase activity assay in our study. However, the synthesized compound 6 inhibited neuraminidase at higher rate than quercetin. It was declared that the flavonoid and phenolic compounds which are obtained from plants have antineuraminidase activity [ 72,73$]$. The hydroxyl groups exist mostly in the structure of these compounds. There exists sulfur in the synthesized compounds in our study. Sulfoxides have antibacterial and antifungal activities [74]. It can be assumed that the compound 6 which has sulfoxide groups has higher inhibition activity than the compounds that have hydroxyl groups.

This indicates that sulfoxide and halogens bind to active sites of NA enzyme. In our current study, the compound $\mathbf{6}$ which has sulfoxide and halogen groups in its structure has the highest antineuraminidase activity. Compound 6 could be a new lead for further modifications to discover more potent inhibitors.

\section{Materials and Methods}

3.1. General. All chemicals were obtained from commercial suppliers and without further purification. Thin layer chromatography was performed on Merck (60 F 254) TLC-plates (aluminum based). Purifications were carried out by means of column chromatography on silica gel 60 (Merck, 63-200 $\mu \mathrm{m}$ particle size, $60-230$ mesh). Melting points were measured on a Buchi B-540 apparatus and were uncorrected. ${ }^{1} \mathrm{H}$ NMR and

${ }^{13} \mathrm{C}$ NMR spectra were recorded with Varian ${ }^{\text {UNITY }}$ INOVA spectrometers with $500 \mathrm{MHz}$ frequency for ${ }^{1} \mathrm{H}$ and $125 \mathrm{MHz}$ frequency for ${ }^{13} \mathrm{C}$ NMR in ppm $(\delta)$. ${ }^{1} \mathrm{H}$ NMR spectra and ${ }^{13} \mathrm{C}$ NMR spectra in $\mathrm{CDCl}_{3}$ refer to the solvent signal center at $\delta 7.2$ and $\delta 77 \mathrm{ppm}$, respectively. IR spectra were recorded by ATR on Thermo Scientific Nicolet 6700 spectrometer. Mass spectra were recorded on Shimadzu LCMS-8030 triple quadrupole spectrometer in ESI (+) polarity.

3.2. Synthesis of S-Substituted Polyhalonitrobuta-1,3-dienes $\mathbf{3} \boldsymbol{a}$, $\boldsymbol{b}$. In this study compounds $\mathbf{l a}$ and $\mathbf{1 b}$ were used as starting compounds. Pentachloro-2-nitrobuta-1,3-diene (1a) was prepared from $2 \mathrm{H}$-pentachlorobuta-1,3-diene in $43 \%$ yield (bp. $90-96^{\circ} \mathrm{C}$ ) following the literature procedure [54]. 4Bromo-tetrachloro-2-nitrobuta-1,3-diene (1b) was prepared from $2 \mathrm{H}$-4-bromo-tetrachlorobuta-1,3-diene in $40 \%$ yield (bp. $68-70^{\circ} \mathrm{C}$ ) following the literature procedure [55]. 1-(Allylthio)-1,3,4,4-tetrachloro-2-nitrobuta-1,3-diene (3a) and 1-(Allylthio)-4-bromo-1,3,4-trichloro-2-nitrobuta-1,3-diene (3b) were prepared using the procedure according to the reported literature $[49,50]$. 
TABLE 3: The elastase inhibitory activity of different concentrations of S-substituted perhalonitrobuta-1,3-diene compounds.

\begin{tabular}{|c|c|c|c|}
\hline $\begin{array}{l}\text { Chemical compounds and } \\
\text { standard }\end{array}$ & Concentration $(\mu \mathrm{M})$ & Inhibition $(\%)^{*}$ & $\mathrm{IC}_{50}(\mu \mathrm{M})^{*}$ \\
\hline \multirow{5}{*}{4} & 2000 & $58.55 \pm 2.37$ & \multirow{5}{*}{$1476.79 \pm 56.03$} \\
\hline & 1000 & $45.19 \pm 0.23$ & \\
\hline & 500 & $34.12 \pm 2.25$ & \\
\hline & 250 & $13.32 \pm 1.99$ & \\
\hline & 125 & $8.24 \pm 0.55$ & \\
\hline \multirow{5}{*}{$5 a$} & 2000 & $20.23 \pm 0.78$ & \multirow{5}{*}{$9116.60 \pm 1068.43$} \\
\hline & 1000 & $14.36 \pm 0.30$ & \\
\hline & 500 & $13.66 \pm 0.08$ & \\
\hline & 125 & $12.74 \pm 0.04$ & \\
\hline & 60 & $10.09 \pm 0.42$ & \\
\hline \multirow{5}{*}{$5 b$} & 2000 & $36.81 \pm 1.65$ & \multirow{5}{*}{$2605.75 \pm 150.87$} \\
\hline & 1000 & $30.03 \pm 1.67$ & \\
\hline & 500 & $18.68 \pm 1.10$ & \\
\hline & 250 & $4.66 \pm 1.37$ & \\
\hline & 125 & $3.94 \pm 0.05$ & \\
\hline \multirow{5}{*}{6} & 1000 & $27.09 \pm 0.66$ & \multirow{5}{*}{$2024.74 \pm 139.82$} \\
\hline & 500 & $23.31 \pm 1.07$ & \\
\hline & 250 & $16.19 \pm 1.44$ & \\
\hline & 125 & $10.22 \pm 0.81$ & \\
\hline & 60 & $8.23 \pm 1.66$ & \\
\hline \multirow{5}{*}{ Ursolic acid } & 1000 & $76.74 \pm 0.38$ & \multirow{5}{*}{$424.10 \pm 5.15$} \\
\hline & 500 & $72.27 \pm 0.51$ & \\
\hline & 250 & $49.33 \pm 0.06$ & \\
\hline & 125 & $27.60 \pm 1.56$ & \\
\hline & 60 & $12.20 \pm 0.50$ & \\
\hline
\end{tabular}

${ }^{*}$ Mean \pm SD.

TABLE 4: The neuraminidase inhibitory activity of different concentrations of S-substituted perhalonitrobuta-1,3-diene compounds.

\begin{tabular}{|c|c|c|c|}
\hline $\begin{array}{l}\text { Chemical compounds and } \\
\text { standard }\end{array}$ & Concentration $(\mu \mathrm{M})$ & Inhibition $(\%)^{*}$ & $\mathrm{IC}_{50}(\mu \mathrm{M})^{*}$ \\
\hline \multirow{5}{*}{ 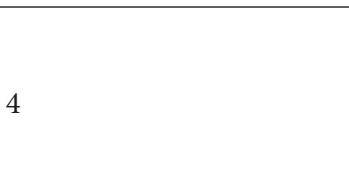 } & 100 & $18.16 \pm 1.26$ & \multirow{5}{*}{$458.90 \pm 62.62$} \\
\hline & 10 & $13.70 \pm 0.23$ & \\
\hline & 1 & $10.73 \pm 0.23$ & \\
\hline & 0.1 & $7.97 \pm 0.02$ & \\
\hline & 0.01 & $7.20 \pm 0.12$ & \\
\hline \multirow{5}{*}{$5 a$} & 100 & $21.77 \pm 2.51$ & \multirow{5}{*}{$329.45 \pm 48.44$} \\
\hline & 10 & $16.95 \pm 0.52$ & \\
\hline & 1 & $14.78 \pm 0.27$ & \\
\hline & 0.1 & $11.48 \pm 1.29$ & \\
\hline & 0.01 & $4.89 \pm 0.56$ & \\
\hline \multirow{5}{*}{$5 b$} & 100 & $28.85 \pm 0.49$ & \multirow{5}{*}{$200.23 \pm 5.92$} \\
\hline & 10 & $11.33 \pm 0.38$ & \\
\hline & 1 & $8.89 \pm 0.57$ & \\
\hline & 0.1 & $7.99 \pm 0.79$ & \\
\hline & 0.01 & $6.19 \pm 1.34$ & \\
\hline \multirow{5}{*}{6} & 25 & $56.57 \pm 18.45$ & \multirow{5}{*}{$23.12 \pm 9.62$} \\
\hline & 10 & $23.00 \pm 2.79$ & \\
\hline & 1 & $13.77 \pm 2.62$ & \\
\hline & 0.1 & $8.02 \pm 0.35$ & \\
\hline & 0.01 & $4.30 \pm 0.4$ & \\
\hline \multirow{5}{*}{ Quercetin } & 100 & $32.31 \pm 3.50$ & \multirow{5}{*}{$161.54 \pm 18.21$} \\
\hline & 50 & $21.37 \pm 0.88$ & \\
\hline & 10 & $13.06 \pm 0.29$ & \\
\hline & 1 & $4.58 \pm 0.76$ & \\
\hline & 0.1 & $3.26 \pm 0.05$ & \\
\hline
\end{tabular}

${ }^{*}$ Mean \pm SD. 
1-(Allylthio)-1,3,4,4-tetrachloro-2-nitrobuta-1,3-diene (3a). Yellow crystals. M.p. $=72-73^{\circ} \mathrm{C}$. Yield $40 \%$. FTIR (ATR) v $\left(\mathrm{cm}^{-1}\right)$ 2900, 1600, 1510, 1310, 1295. ${ }^{1} \mathrm{H}-\mathrm{NMR}\left(\mathrm{CDCl}_{3}\right)$ : 5.7$6\left(\mathrm{~m}, 1 \mathrm{H}, \mathrm{CH}={ }_{\text {allyl }}\right), 5.2-5.6\left(\mathrm{~m}, 2 \mathrm{H},=\mathrm{CH}_{2}\right.$ allyl $), 3.6-4(\mathrm{~m}$, $\left.2 \mathrm{H}, \mathrm{CH}_{2 \text { allyl }}\right) .{ }^{13} \mathrm{C}-\mathrm{NMR}\left(\mathrm{CDCl}_{3}\right): 37.7\left(\mathrm{~S}-\mathrm{CH}_{2}\right.$ allyl $), 120.3$ $\left(=\mathrm{CH}_{2}\right.$ allyl $), 129 \quad\left(\mathrm{CH}={ }_{\text {allyl }}\right), \quad 120.4, \quad 127.7, \quad 128.9,155.9$ $\left(\mathrm{C}_{\text {butadiene }}\right)$. MS (ESI), $(\mathrm{m} / z \%): 327.20\left[\mathrm{M}+\mathrm{NH}_{4}\right]^{+}$. $\mathrm{C}_{7} \mathrm{H}_{5} \mathrm{Cl}_{4} \mathrm{NO}_{2} \mathrm{~S}(\mathrm{M}=308.945 \mathrm{~g} / \mathrm{mol})$.

1-(Allylthio)-4-bromo-1,3,4-trichloro-2-nitrobuta-1,3-diene (3b). Yellow oil. Yield 20\%. FTIR (ATR) $v\left(\mathrm{~cm}^{-1}\right)$ 2950, 2900, 1600. ${ }^{1} \mathrm{H}-\mathrm{NMR}\left(\mathrm{CDCl}_{3}\right): 5.8-6\left(\mathrm{~m}, 1 \mathrm{H}, \mathrm{CH}={ }_{\text {allyl }}\right), 5.2-5.5$ $\left(\mathrm{m}, 2 \mathrm{H},=\mathrm{CH}_{2}\right.$ allyl $), 3.6-3.8\left(\mathrm{~m}, 2 \mathrm{H}, \mathrm{CH}_{2}\right.$ allyl $) .{ }^{13} \mathrm{C}-\mathrm{NMR}$ $\left(\mathrm{CDCl}_{3}\right): 37.7\left(\mathrm{~S}-\mathrm{CH}_{2}\right.$ allyl $), 120.4\left(=\mathrm{CH}_{2}\right.$ allyl $), 129\left(\mathrm{CH}{ }_{\text {allyl }}\right)$, $113,129,137.9,155.9\left(\mathrm{C}_{\text {butadiene }}\right)$. MS (ESI), $(\mathrm{m} / z \%): 372[\mathrm{M}+$ $\left.\mathrm{NH}_{4}\right]^{+} . \mathrm{C}_{7} \mathrm{H}_{5} \mathrm{BrCl}_{3} \mathrm{NO}_{2} \mathrm{~S}(\mathrm{M}=353.45 \mathrm{~g} / \mathrm{mol})$.

3.3. Synthesis of 1-(2,3-Dibromopropanethio)-4-bromo-1,3,4trichloro-2-nitrobuta-1,3-diene (4). This compound was synthesized from $3 \mathbf{b}(0.1 \mathrm{~g}, 0.28 \mathrm{mmol})$ and bromine $(0.045 \mathrm{~g}$, $0.28 \mathrm{mmol}$ ) in $\mathrm{CCl}_{4}$. Bromine was added slowly dropwise and stirring continued for 3 hours at room temperature. The progress of the reaction was monitored by TLC. A solution of sodium sulfide and ether was added to the reaction mixture. The organic layer was separated and dried with $\mathrm{Na}_{2} \mathrm{SO}_{4}$. The solvent was evaporated under low pressure. The product was purified by column chromatography. Yellow oil. Yield $21 \%$. FTIR (ATR) $v\left(\mathrm{~cm}^{-1}\right)$ 2957, 2921, 2851, 1592, 1529, 1290. ${ }^{1} \mathrm{H}-$ NMR $\left(\mathrm{CDCl}_{3}\right): 4.2-4.3(\mathrm{~m}, 1 \mathrm{H}, \mathrm{CH}-\mathrm{Br}), 3.6-3.9(\mathrm{~m}, 2 \mathrm{H}$, $\left.\mathrm{CH}_{2}-\mathrm{Br}\right)$, 3.3-3.5 (m, 2H, S-CH $\left.{ }_{2}\right) .{ }^{13} \mathrm{C}-\mathrm{NMR}\left(\mathrm{CDCl}_{3}\right)$ : $31(\mathrm{~S}-$ $\left.\mathrm{CH}_{2}\right), 33.6\left(\mathrm{CH}_{2}-\mathrm{Br}\right), 46.1$ (CH-Br), 114, 121.3, 123.08, 153 $\left(\mathrm{C}_{\text {butadiene }}\right)$. MS (ESI), $(m / z \%): 531.30\left[\mathrm{M}+\mathrm{NH}_{4}\right]^{+}, 497.50$ $\left[\mathrm{M}+\mathrm{NH}_{4}-\mathrm{Cl}\right]^{+}, 461.90\left[\mathrm{M}+\mathrm{NH}_{4}-2 \mathrm{Cl}\right]^{+} . \mathrm{C}_{7} \mathrm{H}_{5} \mathrm{Br}_{3} \mathrm{Cl}_{3} \mathrm{NO}_{2} \mathrm{~S}$ $(\mathrm{M}=513.16 \mathrm{~g} / \mathrm{mol})$.

3.4. General Procedure for the Synthesis of Sulfoxides 5a, 5b, 6. Compound $\mathbf{3 a}, \mathbf{3 b}$, or $\mathbf{4}(1 \mathrm{mmol})$ in $30 \mathrm{~mL}$ of chloroform was mixed with $m$-chloroperbenzoic acid $(4 \mathrm{mmol})$ in $30 \mathrm{~mL}$ of chloroform at $0^{\circ} \mathrm{C}$ for $24 \mathrm{~h}$. The progress of the reaction was monitored by TLC. A solution of $2 \mathrm{M} \mathrm{NaOH}$ and chloroform was added to the reaction mixture. The organic layer was separated and dried with $\mathrm{Na}_{2} \mathrm{SO}_{4}$. The solvent was evaporated under low pressure. The product was purified by column chromatography.

1-(Allylsulfinyl)-1,3,4,4-tetrachloro-2-nitrobuta-1,3-diene (5a). This compound was synthesized from $3 a(0.058 \mathrm{~g}, 0.18 \mathrm{mmol})$ and $m$-chloroperbenzoic acid $(0.12 \mathrm{~g}, 0.72 \mathrm{mmol})$ according to the general procedure. White crystals. M.p $=195-196^{\circ} \mathrm{C}$. Yield 28\%. FTIR (ATR) $v\left(\mathrm{~cm}^{-1}\right)$ 2957, 2914, 2856, 1570, 1462, 1267, 1071. ${ }^{13} \mathrm{C}-\mathrm{NMR}\left(\mathrm{CDCl}_{3}\right): 40.4\left(\mathrm{SO}-\mathrm{CH}_{2}\right.$ allyl $)$, $109.9\left(=\mathrm{CH}_{2}\right.$ allyl $), 131\left(\mathrm{CH}={ }_{\text {allyl }}\right), 128,133,134,166\left(\mathrm{C}_{\text {butadiene }}\right)$. MS (ESI), $(m / z \%): 343.0\left[\mathrm{M}+\mathrm{NH}_{4}\right]^{+}, 326.0[\mathrm{M}+\mathrm{H}]^{+}$. $\mathrm{C}_{7} \mathrm{H}_{5} \mathrm{Cl}_{4} \mathrm{NO}_{3} \mathrm{~S}(\mathrm{M}=325 \mathrm{~g} / \mathrm{mol})$.

1-(Allylsulfinyl)-4-bromo-1,3,4-trichloro-2-nitrobuta-1,3-diene $(5 \boldsymbol{b})$. This compound was synthesized from $3 \mathbf{b}(0.026 \mathrm{~g}$,
$0.84 \mathrm{mmol})$ and $m$-chloroperbenzoic acid ( $0.18 \mathrm{~g}, 0.72 \mathrm{mmol})$ according to the general procedure. White oil. Yield $17 \%$. FTIR (ATR) $v\left(\mathrm{~cm}^{-1}\right)$ 2957, 2924, 2855, 1578, 1461, 1271, 1071. MS (ESI), $(m / z \%): 387.20\left[\mathrm{M}+\mathrm{NH}_{4}\right]^{+}, 369.90[\mathrm{M}+\mathrm{H}]^{+}$. $\mathrm{C}_{7} \mathrm{H}_{5} \mathrm{BrCl}_{3} \mathrm{NO}_{3} \mathrm{~S}(\mathrm{M}=369.45 \mathrm{~g} / \mathrm{mol})$.

1-(2,3-Dibromopropylsulfinyl)-4-bromo-1,3,4-trichloro-2nitrobuta-1,3-diene (6). This compound was synthesized from $4(0.02 \mathrm{~g}, 0.038 \mathrm{mmol})$ and $m$-chloroperbenzoic acid $(0.006 \mathrm{~g}, 0.15 \mathrm{mmol})$ according to the general procedure. White crystals. M.p $=103-105^{\circ}$ C. Yield 15\%. FTIR (ATR) $\nu\left(\mathrm{cm}^{-1}\right)$ 2918, 2849, 1690, 1573, 12891, 1073. MS (ESI), $(m / z \%): 548.15\left[\mathrm{M}+\mathrm{NH}_{4}\right]^{+}, 492.50\left[\mathrm{M}+\mathrm{NH}_{4}-\mathrm{Cl}\right]^{+}$. $\mathrm{C}_{7} \mathrm{H}_{5} \mathrm{Br}_{3} \mathrm{Cl}_{3} \mathrm{NO}_{3} \mathrm{~S}(\mathrm{M}=529.26 \mathrm{~g} / \mathrm{mol})$.

\subsection{Enzyme Inhibition}

3.5.1. Xanthine Oxidase Inhibitory Activity. XO inhibitory activity was determined spectrophotometrically by using xanthine as the substrate [75]. The assay mixture consisted of samples, phosphate buffer ( $\mathrm{pH}$ : 7.5), and xanthine oxidase enzyme solution $(0,1 \mathrm{U} / \mathrm{mL}$ in phosphate buffer, $\mathrm{pH}$ : 7.5$)$ which was prepared immediately before use. After preincubation at $25^{\circ} \mathrm{C}$ for $15 \mathrm{mins}$, the reaction was initiated by substrate solution. The assay mixture was incubated for 30 minutes. Then, the reaction was stopped by adding $\mathrm{HCl}$. Absorbance value was measured at $290 \mathrm{~nm}$ by using UV spectrophotometer. XO inhibitory activity was expressed as the percentage of the inhibition of XO in the assay system above, calculated as

$$
\text { inhibition }(\%)=\left(1-\left[\frac{B}{A}\right]\right) \times 100 \text {, }
$$

where $A$ represents the activity of the enzyme without sample and $B$ is the activity of $\mathrm{XO}$ in the presence of the sample. Allopurinol was used as a standard compound as control.

3.5.2. Tyrosinase Inhibitory Activity. Tyrosinase inhibitory activity was determined spectrophotometrically [76]. Briefly, test reaction mixtures were prepared by adding mushroom tyrosinase, sample, L-tyrosine, and sodium phosphate buffer (pH 6.5). The resulting mixture was incubated for $10 \mathrm{mins}$ at $37^{\circ} \mathrm{C}$ and absorption value was measured at $475 \mathrm{~nm}$. The percentage of the inhibition of tyrosinase activity was calculated according to the following equation:

$$
\text { inhibition }(\%)=\left[\frac{(A-B)}{A}\right] \times 100 \text {, }
$$

where $A$ represents the activity of the enzyme without sample and $B$ is the activity of tyrosinase in the presence of the sample. Kojic acid was used as a standard compound as control.

3.5.3. Elastase Inhibitory Activity. Elastase inhibitory activity was examined in this study by using N-Succinyl-Ala-Ala-ProPhe p-nitroanilide (STANA) as a substrate and by measuring the release of p-nitroanilide at $410 \mathrm{~nm}$ [77]. The percentage 
of the inhibition of elastase was calculated according to the following equation:

$$
\text { inhibition }(\%)=\left[\frac{(A-B)}{A}\right] \times 100 \text {, }
$$

where $A$ represents the activity of the enzyme without sample and $B$ is the activity of elastase in the presence of the sample. Ursolic acid was used as a standard compound as control.

3.5.4. Neuraminidase Inhibitory Activity. NA inhibitory activity was determined by using the method described by Myers et al. [78] with some modification. The reaction was carried out with the enzyme $\left(2.5 \times 10^{-3} \mathrm{U} / \mathrm{mL}\right)$, acetate buffer (pH: 5.0), and sample substrate (4-methylumbelliferyl-a-D$\mathrm{N}$-acetylneuraminic acid sodium salt hydrate, $0.125 \mathrm{mM}$ ) and was incubated for 10 minutes at $37^{\circ} \mathrm{C}$. After reaction was stopped by adding glycine- $\mathrm{NaOH}$ buffer ( $\mathrm{pH}$ : 10.4), the fluorescence of reactions was measured spectrofluorometrically. The emission wavelength was $440 \mathrm{~nm}$, while excitation wavelength was $360 \mathrm{~nm}$. The percentage of the inhibition was obtained by the equation below:

$$
\begin{aligned}
& \text { inhibition }(\%)=[(\text { rate of control reaction }) \\
& \left.-\frac{(\text { rate of sample reaction })}{(\text { rate of control reaction })}\right] \times 100 \text {. }
\end{aligned}
$$

Quercetin was applied as a standard compound as control.

The Ki values and inhibition types for compound 6 and quercetin were calculated by Lineweaver Burk curves for neuraminidase enzyme [79].

For all the enzyme inhibition, the results are given as half maximal inhibitory concentrations $\left(\mathrm{IC}_{50}\right)$ values, calculated from the regression equations prepared from the concentrations of samples.

\section{Conclusions}

Nitro and sulfoxide compounds have many biological activities such as antiulcer, antibacterial, antifungal, anticancer, and antihypertensive activities [10-16, 27-29]. However, antixanthine oxidase, antityrosinase, antielastase, and antineuraminidase activities of these compounds have not been investigated until now. Therefore, we have synthesized some new derivatives of S-substituted perhalonitrobutadiene and sulfoxide. Many of them have shown good xanthine oxidase, tyrosinase, and neuraminidase inhibitions in this study. For this reason, $\mathrm{S}$-substituted perhalonitrobuta-1,3-dienes may be considered as main neuraminidase, tyrosinase, and xanthine oxidase inhibitors. These compounds can be used in pharmacy, cosmetic, and food industries due to their excellent antixanthine oxidase, antityrosinase, and antineuraminidase activities.

\section{Conflicts of Interest}

The authors declare that they have no conflicts of interest.

\section{Acknowledgments}

The authors gratefully acknowledge the financial support from Istanbul University (Project no. 28347).

\section{References}

[1] L. Bianchi, G. Giorgi, M. Maccagno, G. Petrillo, C. Scapolla, and C. Tavani, "On the behavior of bis(sulfonyl)nitrobutadienes towards primary amines: a convenient access to 1-alkyl-2-aryl4-(phenylsulfonyl)pyrroles," Tetrahedron, vol. 72, no. 44, pp. 7050-7058, 2016.

[2] S. Karimi, S. Ma, Y. Liu et al., "Substituted pyrrole synthesis from nitrodienes," Tetrahedron Letters, vol. 58, no. 23, pp. 2223-2227, 2017.

[3] L. Bianchi, A. Carloni-Garaventa, M. Maccagno et al., "Synthesis of poly-functionalized pyrazoles and pyridazines from nitrobutadienes: an interesting dichotomy of practical relevance," Tetrahedron, vol. 71, no. 40, pp. 7550-7561, 2015.

[4] L. Bianchi, M. Maccagno, M. Pani, G. Petrillo, C. Scapolla, and C. Tavani, "A straight access to functionalized carbazoles by tandem reaction between indole and nitrobutadienes," Tetrahedron, vol. 71, no. 39, Article ID 26764, pp. 7421-7435, 2015.

[5] R. V. Kaberdin, V. I. Potkin, and V. A. Zapol'skii, "Nitrobutadienes and their halogen derivatives: synthesis and reactions," Russian Chemical Reviews, vol. 66, no. 10, pp. 827-842, 1997.

[6] V. A. Zapol'skii, J. C. Namyslo, A. E. W. Adam, and D. E. Kaufmann, "Chemistry of polyhalogenated nitrobutadienes, 1: A new synthesis of perfunctionalized 3-amino-4-nitrothiophenes," Heterocycles, vol. 63, no. 6, pp. 1281-1298, 2004.

[7] V. A. Zapol'skii, J. C. Namyslo, M. Gjikaj, and D. E. Kaufmann, "Chemistry of polyhalogenated nitrobutadienes, 14: Efficient synthesis of functionalized (Z)-2-allylidenethiazolidin-4-ones," Beilstein Journal of Organic Chemistry, vol. 10, pp. 1638-1644, 2014.

[8] L. Bianchi, A. Carloni-Garaventa, M. MacCagno, G. Petrillo, C. Scapolla, and C. Tavani, "Highly-substituted pyrazoles and pyridazines by MIRC reactions of hydrazone anions and nitrobutadienic fragments," Tetrahedron Letters, vol. 53, no. 47, pp. 6394-6400, 2012.

[9] L. Bianchi, C. Dell'Erba, M. Maccagno et al., "Nitrobutadienes from $\beta$-nitrothiophenes: Valuable building-blocks in the overall ring-opening/ring-closure protocol to homo- or hetero-cycles," Arkivoc, vol. 2006, no. 7, pp. 169-185, 2006.

[10] M. Bürgi, V. A. Zapol'skii, B. Hinkelmann et al., "Screening and characterization of molecules that modulate the biological activity of IFNs-I," Journal of Biotechnology, vol. 233, pp. 6-16, 2016.

[11] C. Tavani, L. Bianchi, A. De Palma et al., "Nitro-substituted tetrahydroindolizines and homologs: design, kinetics, and mechanism of $\alpha$-glucosidase inhibition," Bioorganic and Medicinal Chemistry Letters, vol. 27, no. 17, pp. 3980-3986, 2017.

[12] G. Bolger, S. Roy, V. A. Zapol'skii et al., "Targeting aphA: A new high-throughput screening assay identifies compounds that reduce prime virulence factors of Vibrio cholerae," Journal of Medical Microbiology, vol. 65, no. 7, pp. 678-687, 2016.

[13] V. A. Zapol'skii, R. Fischer, J. C. Namyslo, and D. E. Kaufmann, "Chemistry of polyhalogenated nitrobutadienes, 8: Nitropolychlorobutadienes-Precursors for insecticidal neonicotinoids," Bioorganic and Medicinal Chemistry, vol. 17, no. 12, pp. 42064215, 2009. 
[14] G. Petrillo, C. Fenoglio, E. Ognio et al., "Naphthylnitrobutadienes as pharmacologically active molecules: Evaluation of the in vivo antitumour activity," Investigational New Drugs, vol. 25, no. 6, pp. 535-544, 2007.

[15] V. A. Zapol'Skii, J. C. Namyslo, G. Sergeev, M. Brönstrup, M. Gjikaj, and D. E. Kaufmann, "Reinvestigation of the nitration of trichloroethene - Subsequent reactions of the products and evaluation of their antimicrobial and antifungal activity," European Journal of Organic Chemistry, vol. 2015, no. 35, pp. 7763-7774, 2015.

[16] G. Sergeev, S. Roy, M. Jarek et al., "High-throughput screening and whole genome sequencing identifies an antimicrobially active inhibitor of Vibrio cholerae," BMC Microbiology, vol. 14, no. 1, pp. 49-62, 2014.

[17] S. Mahavir, D. E. Kaufmann, V. A. Zapol'skii, and W. Oehlmann, "Preperation of 4-Nitro-5-dichloromethylprazol derivatives for the treatment of infectious diseases," European Patent Application, Article ID 20150128, 2015.

[18] R. Fischer, P. Jeschke, A. Lubos-Erdelen et al., "Halogenated nitrobutadienes for controlling animal pests," US Patent, 2008.

[19] R. Fischer, P. Jeschke, A. Lubos-Erdelen et al., "Preperation of halogenated nitrobutadienes as insecticides," PCT International Appllications, 2003.

[20] Y.-H. Won and M.-S. Park, "Synthesis and anticancer activities of new 3-allylthio-6-(mono or disubstituted)aminopyridazines," Archives of Pharmacal Research, vol. 33, no. 2, pp. 189196, 2010

[21] H. Nian, B. Delage, J. T. Pinto, and R. H. Dashwood, "Allylmercaptan, a garlic derived organosulfur compound inhibits histone deacetylase and enchances Sp3 binding on the P21WAF1," Carcinogenesis, vol. 29, no. 9, pp. 1816-1824, 2008.

[22] J. C. Harris, S. L. Cottrell, S. Plummer, and D. Lloyd, "Antimicrobial properties of Allium sativum (garlic)," Applied Microbiology and Biotechnology, vol. 57, no. 3, pp. 282-286, 2001.

[23] K. H. Kyung, "Antimicrobial properties of allium species," Current Opinion in Biotechnology, vol. 23, no. 2, pp. 142-147, 2012.

[24] S. Melino, R. Sabelli, and M. Paci, "Allyl sulfur compounds and cellular detoxification system: Effects and perspectives in cancer therapy," Amino Acids, vol. 41, no. 1, pp. 103-112, 2011.

[25] B. H. S. Cho and S. Xu, "Effects of allyl mercaptan and various allium-derived compounds on cholesterol synthesis and secretion in Hep-G2 cells," Comparative Biochemistry and PhysiologyC Pharmacology Toxicology and Endocrinology, vol. 126, no. 2, pp. 195-201, 2000.

[26] S. Xu and B. H. S. Cho, "Allyl mercaptan, a major metabolite of garlic compounds, reduces cellular cholesterol synthesis and its secretion in Hep-G2 cells," The Journal of Nutritional Biochemistry, vol. 10, no. 11, pp. 654-659, 1999.

[27] J. B. Arterburn, M. C. Perry, S. L. Nelson, B. R. Dible, and M. S. Holguin, "Rhenium-catalyzed oxidation of thiols and disulfides with sulfoxides," Journal of the American Chemical Society, vol. 119, no. 39, pp. 9309-9310, 1997.

[28] T. G. Back, K. N. Clary, and D. Gao, "Cycloadditions and cyclizations of acetylenic, allenic, and conjugated dienyl sulfones," Chemical Reviews, vol. 110, no. 8, pp. 4498-4553, 2010.

[29] J. H. Lee, S. H. Park, and H. Lee, "S-Acyl and N-Acyl derivatives of benzothiazole-2-thiol: An example of acyl group rearrangement," Bullettin of The Korean Chemical Society, vol. 28, pp. 12111214, 2007.

[30] K. Okamoto, B. T. Eger, T. Nishino, S. Kondo, E. F. Pai, and T. Nishino, "An extremely potent inhibitor of xanthine oxidoreductase: crystal structure of the enzyme-inhibitor complex and mechanism of inhibition," The Journal of Biological Chemistry, vol. 278, no. 3, pp. 1848-1855, 2003.

[31] R. Hille, "The mononuclear molybdenum enzymes," Chemical Reviews, vol. 96, no. 7, pp. 2757-2816, 1996.

[32] F. Braga, S. Pasqualetti, S. Ferraro, and M. Panteghini, "Hyperuricemia as risk factor for coronary heart disease incidence and mortality in the general population: a systematic review and meta-analysis," Clinical Chemistry and Laboratory Medicine, vol. 54, no. 1, pp. 7-15, 2016.

[33] B. Halliwell, J. M. C. Gutteridge, and C. E. Cross, "Free radicals, antioxidants, and human disease: where are we now?" Journal of Laboratory and Clinical Medicine, vol. 119, no. 6, pp. 598-620, 1992.

[34] D. Yadav, E. S. Lee, H. M. Kim et al., "Prospective study of serum uric acid levels and incident metabolic syndrome in a Korean rural cohort," Atherosclerosis, vol. 241, no. 1, pp. 271-277, 2015.

[35] M. V. N. Rodrigues, A. F. Barbosa, J. F. Da Silva et al., "9-Benzoyl 9-deazaguanines as potent xanthine oxidase inhibitors," Bioorganic and Medicinal Chemistry, vol. 24, no. 2, pp. 226-231, 2016.

[36] W. Xie, J. Zhang, X. Ma et al., "Synthesis and Biological Evaluation of Kojic Acid Derivatives Containing 1,2,4-triazole as Potent Tyrosinase Inhibitors," Chemical Biology and Drug Design, vol. 86, no. 5, pp. 1087-1092, 2015.

[37] Z. Ashraf, M. Rafiq, S.-Y. Seo, M. M. Babar, and N.-U. S. Zaidi, "Synthesis, kinetic mechanism and docking studies of vanillin derivatives as inhibitors of mushroom tyrosinase," Bioorganic \& Medicinal Chemistry, vol. 23, no. 17, pp. 5870-5880, 2015.

[38] E. L. Cavalieri, K.-M. Li, N. Balu et al., "Catechol ortho-quinones: the electrophilic compounds that form depurinating DNA adducts and could initiate cancer and other diseases," Carcinogenesis, vol. 23, no. 6, pp. 1071-1077, 2002.

[39] T. Pan, X. Li, and J. Jankovic, "The association between Parkinson's disease and melanoma," International Journal of Cancer, vol. 128, no. 10, pp. 2251-2260, 2011.

[40] Z. Ashraf, M. Rafiq, S.-Y. Seo, M. M. Babar, and N.-U. S. Zaidi, "Synthesis, kinetic mechanism and docking studies of vanillin derivatives as inhibitors of mushroom tyrosinase," Bioorganic and Medicinal Chemistry, vol. 23, no. 17, pp. 5870-5880, 2015.

[41] J. Wu, X. Hu, and L. Ma, "Synthesis and biological evaluation of polyhydroxy benzophenone as mushroom tyrosinase inhibitors," Journal of Enzyme Inhibition and Medicinal Chemistry, vol. 26, no. 3, pp. 449-452, 2011.

[42] B. B. Sokmen, N. Gumrukcuoglu, S. Ugras, H. I. Ugras, and R. Yanardag, "Synthesis, antibacterial, antielastase, antiurease and antioxidant activities of new methoxy substitued bis-1,2,4triazole derivatives," Journal of Enzyme Inhibition and Medicinal Chemistry, vol. 28, no. 1, pp. 72-77, 2013.

[43] Z.-C. Li, L.-H. Chen, X.-J. Yu et al., "Inhibition kinetics of chlorobenzaldehyde thiosemicarbazones on mushroom tyrosinase," Journal of Agricultural and Food Chemistry, vol. 58, no. 23, pp. 12537-12540, 2010.

[44] M. Piagnerelli, K. Z. Boudjeltia, D. Brohee et al., "Alterations of red blood cell shape and sialic acid membrane content in septic patients," Critical Care Medicine, vol. 31, no. 8, pp. 2156-2162, 2003.

[45] C. Colombo, B. M. Pinto, A. Bernardi, and A. J. Bennet, "Synthesis and evaluation of influenza A viral neuraminidase candidate inhibitors based on a bicyclo[3.1.0] hexane scaffold," Organic \& Biomolecular Chemistry, vol. 14, no. 27, pp. 65396553, 2016. 
[46] T. Jefferson, M. Jones, P. Doshi, and C. Del Mar, "Neuraminidase inhibitors for preventing and treating influenza in healthy adults: systematic review and meta-analysis," BMJ (Clinical research ed.), vol. 339, Article ID b5106, 2009.

[47] C. Sun, X. Zhang, H. Huang, and P. Zhou, "Synthesis and evaluation of a new series of substituted acyl(thio)urea and thiadiazolo [2,3-a] pyrimidine derivatives as potent inhibitors of influenza virus neuraminidase," Bioorganic \& Medicinal Chemistry, vol. 14 , no. 24, pp. 8574-8581, 2006.

[48] A. Akincioğlu, Y. Akbaba, H. Göçer, S. Göksu, I. Gülçin, and C. T. Supuran, "Novel sulfamides as potential carbonic anhydrase isoenzymes inhibitors," Bioorganic \& Medicinal Chemistry, vol. 21, no. 6, pp. 1379-1385, 2013.

[49] C. Ibis and N. B. Yilmaz, "S-, S,S-, S,S,S- and N,S-substituted diene compounds and diabutadienyl piperazine compounds of 2-nitropentachlorobutadiene," Phosphorus, Sulfur, and Silicon and the Related Elements, vol. 177, no. 3, pp. 695-701, 2002.

[50] C. Ibis and N. Onul, "New N,S-derivatives of nitrodienes from thioallyl- and thiodibromopropyl nitrodienes," Phosphorus, Sulfur, and Silicon and the Related Elements, vol. 181, no. 10, pp. 2411-2417, 2006.

[51] C. Ibis and N. Y. Onul, "The new S- and N,S-substituted nitrodienes from bromochloro-2-nitrodiene," Revue Roumaine de Chimie, vol. 52, no. 10, pp. 953-956, 2007.

[52] C. Ibis, F. G. Kirbaşlar, and G. Aydinli, "Novel N,S-substituted dienes from reaction of mono(aryl-substituted polyhalo-2nitro dienes with amines," Phosphorus, Sulfur, and Silicon and the Related Elements, vol. 180, no. 2, pp. 365-374, 2005.

[53] C. Ibis and F. Ozkok, "The synthesis of novel S-, S,S-, S,S,S-, SyO-y N,S-substituted halogenobuta-1,3-dienes," Acta Chimica Slovenica, vol. 59, no. 2, pp. 294-301, 2012.

[54] Y. A. Oldekop and R. V. Kaberdin, "2-Nitropentachloro-1, 3butadiene," Zhurnal Organicheskoi Khimii, vol. 12, pp. 20392040, 1976.

[55] Y. A. Oldekop, R. V. Kaberdin, and V. I. Potkin, "Synthesis and properties of mixed perhalo derivatives of 2-nitro-1, 3-butadiene," Zhurnal Organicheskoi Khimii, vol. 22, pp. 1389-1393, 1986.

[56] N. G. Deniz and C. İbis, "The vinylic $S_{N}$ reactions of nitrodienes with heteroatom-substituted nuchleophilies and their structural studies," Heteroatom Chemistry, vol. 26, no. 1, pp. 51-62, 2015.

[57] C. İbis, A. F. Tuyun, and G. Aydinli, "The synthesis of new S- and N,S-substituted halo nitro dienes by the reactions of 1-bromo1,2,4,4-tetrachloro-3-nitrobuta-1,3-diene with thiols and cyclic amines," Phosphorus, Sulfur, and Silicon and the Related Elements, vol. 185, no. 10, pp. 2014-2023, 2010.

[58] C. İbis, M. C. Sayil, and N. G. Deniz, "1,3,4,4-Tetrachloro-4-(4chlorophenyl-sulfanyl)-2-nitrobuta-1,3-diene," Acta Crystallographica Section E: Structure Reports Online, vol. 62, no. 2, pp. 0800-0801, 2006.

[59] M. R. Ali, S. Kumar, O. Afzal et al., "2-Benzamido-4-methylthiazole-5-carboxylic acid derivatives as potential xanthine oxidase inhibitors and free radical scavengers," Archiv der Pharmazie, vol. 350, no. 2, Article ID 1600313, 2017.

[60] J. U. Song, J. W. Jang, T. H. Kim et al., "Structure-based design and biological evaluation of novel 2-(indol-2-yl) thiazole derivatives as xanthine oxidase inhibitors," Bioorganic \& Medicinal Chemistry Letters, vol. 26, no. 3, pp. 950-954, 2016.

[61] J. U. Song, S. P. Choi, T. H. Kim et al., "Design and synthesis of novel 2-(indol-2-yl) thiazole derivatives as xanthine oxidase inhibitors," Bioorganic and Medicinal Chemistry Letters, vol. 25, pp. 1254-1258, 2015.

[62] Y.-J. Zhu, K.-K. Song, Z.-C. Ll et al., "Antityrosinase and antimicrobial activities of frans- cinnamaldehydethiosemicarbazone," Journal of Agricultural and Food Chemistry, vol. 57, no. 12, pp. 5518-5523, 2009.

[63] P. Liu, C. Shu, L. Liu, Q. Huang, and Y. Peng, "Design and synthesis of thiourea derivatives with sulfur-containing heterocyclic scaffolds as potential tyrosinase inhibitors," Bioorganic \& Medicinal Chemistry, vol. 24, no. 8, pp. 1866-1871, 2016.

[64] Y. M. Ha, Y. J. Park, J.-A. Kim et al., "Design and synthesis of 5(substituted benzylidene)thiazolidine-2,4-dione derivatives as novel tyrosinase inhibitors," European Journal of Medicinal Chemistry, vol. 49, pp. 245-252, 2012.

[65] J. Liu, W. Yi, Y. Wan, L. Ma, and H. Song, "1-(1-Arylethylidene)thiosemicarbazide derivatives: a new class of tyrosinase inhibitors," Bioorganic \& Medicinal Chemistry, vol. 16, no. 3, pp. 1096-1102, 2008

[66] T.-S. Chang, "An updated review of tyrosinase inhibitors," International Journal of Molecular Sciences, vol. 10, no. 6, pp. 2440-2475, 2009.

[67] J. Stolk, J. A. Kramps, and J. H. Dijkman, "In vitro effect of a mucolytic thiol agent on the activity of polymorphonuclear leucocyte elastase and antileucoprotease," Thorax, vol. 41, no. 11, pp. 840-845, 1986.

[68] N. P. Rodis and G. A. Digenis, "Synthesis and in-vitro evaluation of novel low molecular weight thiocarbamates as inhibitors of human leukocyte elastase," Journal of Enzyme Inhibition and Medicinal Chemistry, vol. 16, no. 2, pp. 95-105, 2001.

[69] L. Bachmetov, M. Gal-Tanamy, A. Shapira et al., "Suppression of hepatitis $\mathrm{C}$ virus by the flavonoid quercetin is mediated by inhibition of NS3 protease activity," Journal of Viral Hepatitis, vol. 19, no. 2, pp. e81-e88, 2012.

[70] N. Rojas, J. A. Del Campo, S. Clement et al., "Effect of quercetin on Hepatitis C virus life cycle: From viral to host targets," Scientific Reports, vol. 6, Article ID 31777, 2016.

[71] O. Gonzalez, V. Fontanes, S. Raychaudhuri et al., "The heat shock protein inhibitor quercetin attenuates hepatitis $\mathrm{C}$ virus production," Hepatology, vol. 50, no. 6, pp. 1756-1764, 2009.

[72] S. Bang, T. K. Quy Ha, C. Lee, W. Li, W.-K. Oh, and S. H. Shim, "Antiviral activities of compounds from aerial parts of Salvia plebeia R. Br," Journal of Ethnopharmacology, vol. 192, pp. 398405, 2016.

[73] L. Tian, Z. Wang, H. Wu et al., "Evaluation of the anti-neuraminidase activity of the traditional Chinese medicines and determination of the anti-influenza A virus effects of the neuraminidase inhibitory TCMs in vitro and in vivo," Journal of Ethnopharmacology, vol. 137, no. 1, pp. 534-542, 2011.

[74] J. Drabowski, P. Kielbasininski, and M. Mikolajcyk, Synthesis of sulfoxides, John Wiley and Sons, New York, NY, USA, 1994.

[75] A. Abdullahi, A. Y. Kabiru, A. C. Isah, and M. Z. Kolo, "Inhibitory activity of xanthine oxidase by fractions Crateva adansonii," Journal of Acute Disease, vol. 2, pp. 126-129, 2012.

[76] J.-H. Hwang and B. M. Lee, "Inhibitory effects of plant extracts on tyrosinase, L-DOPA oxidation, and melanin synthesis," Journal of Toxicology and Environmental Health, Part A. Current Issues, vol. 70, no. 5, pp. 393-407, 2007.

[77] J. Moon, E. Yim, G. Song, N. H. Lee, and C. Hyun, "Screening of elastase and tyrosinase inhibitory activity from Jeju Island plants," EurAsian Journal of BioSciences, pp. 41-53, 2010. 
[78] R. W. Myers, R. T. Lee, Y. C. Lee, G. H. Thomas, L. W. Reynolds, and Y. Uchida, "The synthesis of 4-methylumbelliferyl $\alpha$ ketoside of $\mathrm{N}$-acetylneuraminic acid and its use in a fluorometric assay for neuraminidase," Analytical Biochemistry, vol. 101, no. 1, pp. 166-174, 1980.

[79] H. Lineweaver and D. Burk, "The determination of enzyme dissociation constants," Journal of the American Chemical Society, vol. 56, no. 3, pp. 658-666, 1934. 

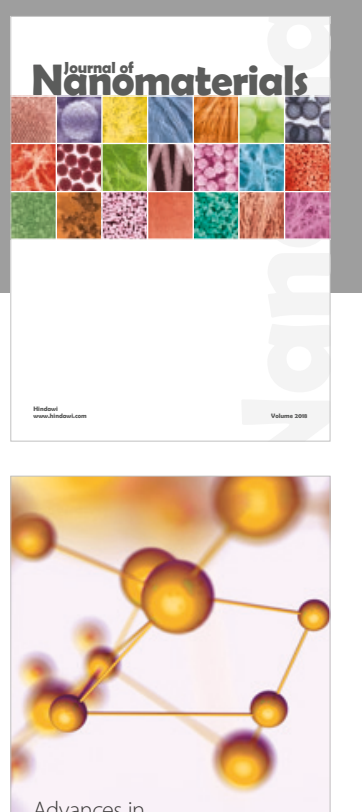

Physical Chemistry
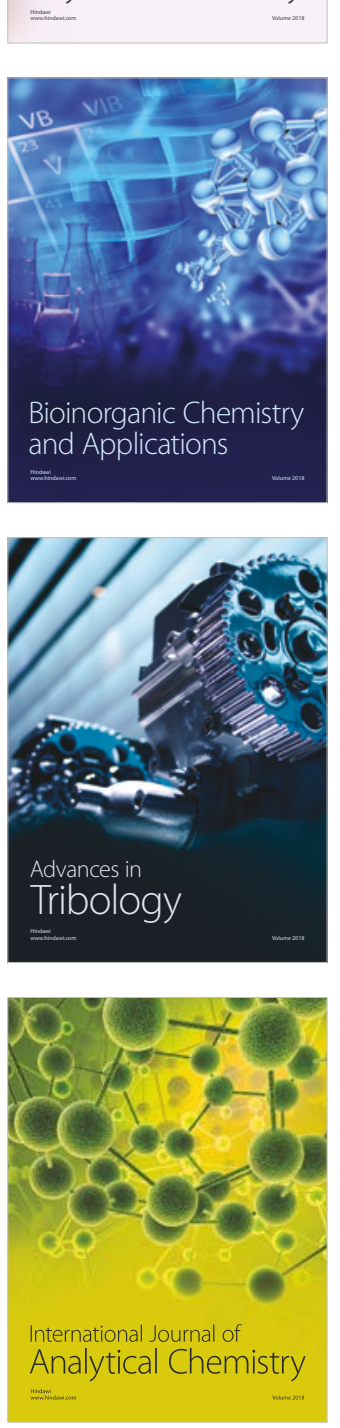

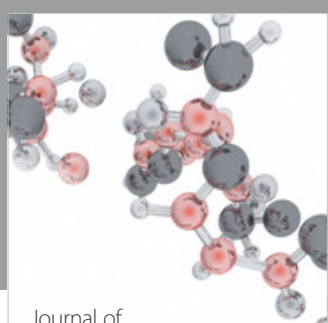

Analytical Methods

in Chemistry

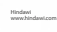

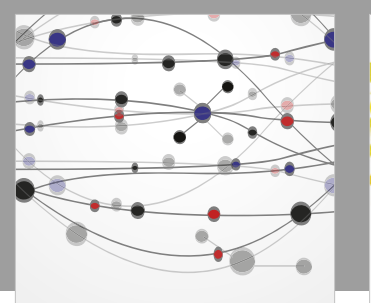

The Scientific World Journal

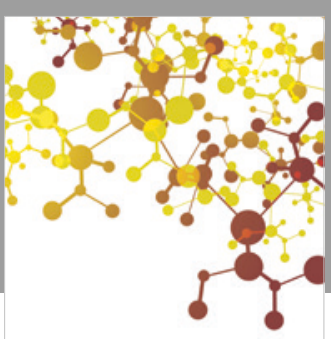

Journal of

Applied Chemistry
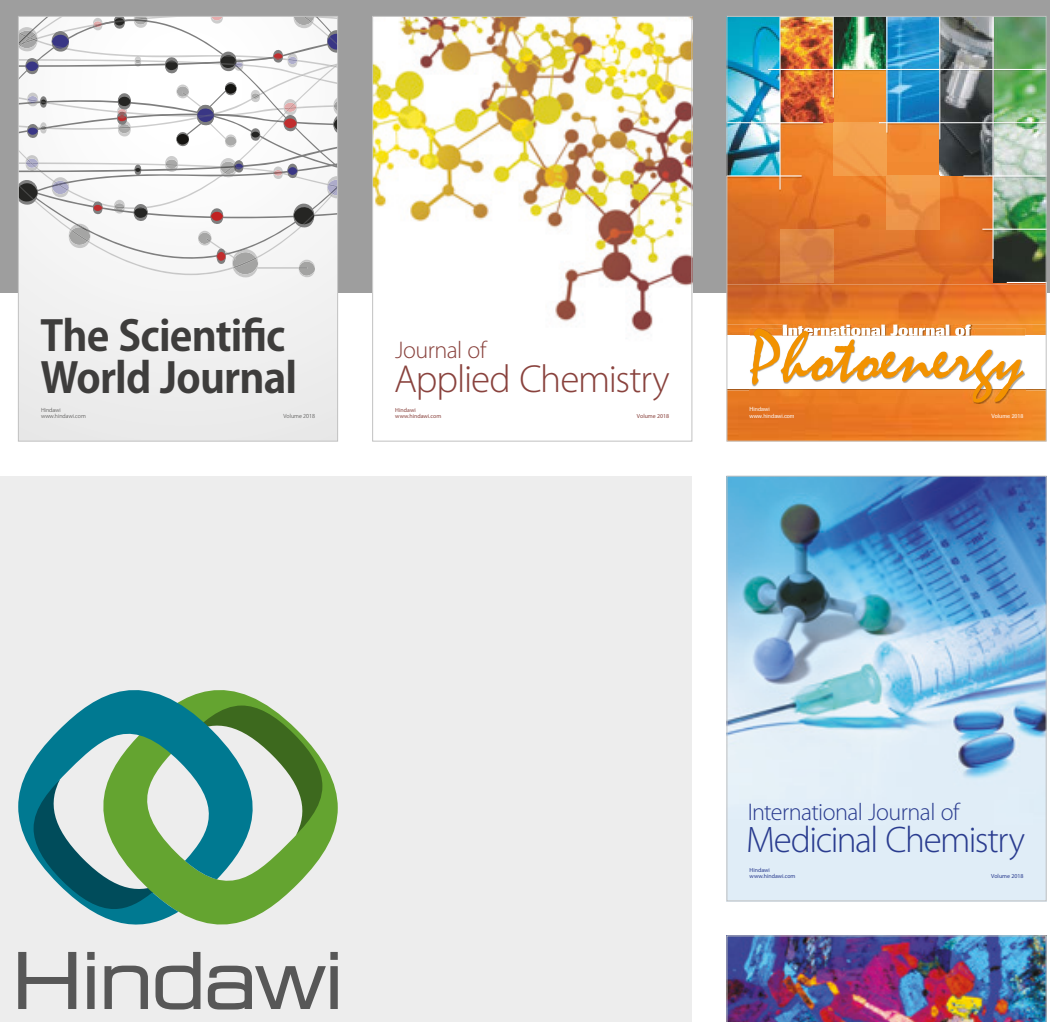

Submit your manuscripts at

www.hindawi.com
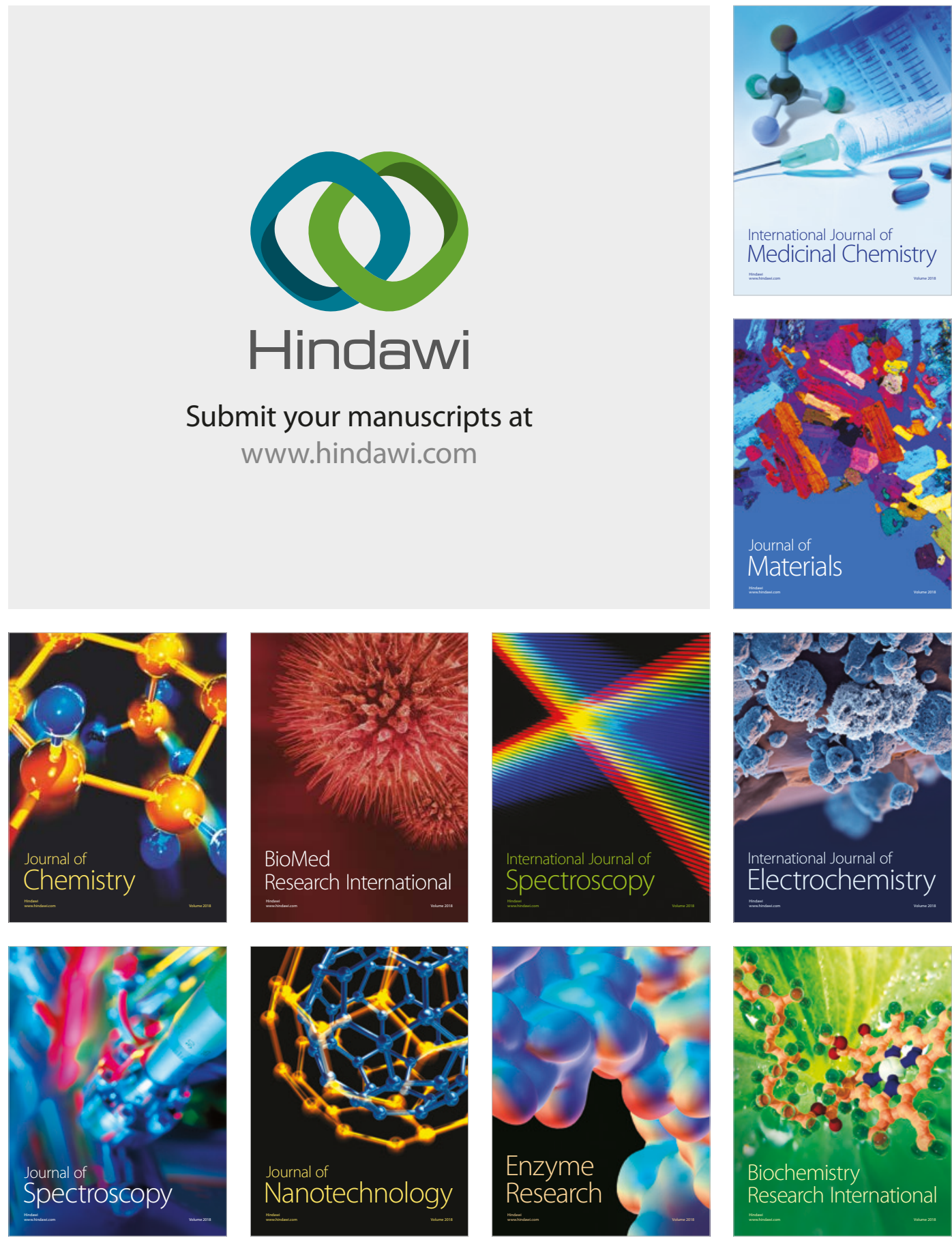
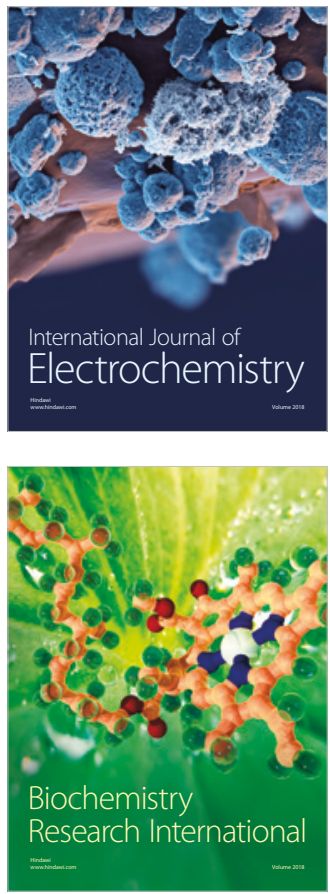